\title{
Alterations in Nitric Oxide Production in 8-Week-Old Lambs with Increased Pulmonary Blood Flow
}

\author{
STEPHEN M. BLACK, JANINE M. BEKKER, D. MICHAEL McMULLAN, ANDREW J. PARRY, \\ BOAZ OVADIA, OLAF REINHARTZ, SATYAN LAKSHMINRUSHIMHA, \\ EUGENIA MATA-GREENWOOD, ROBIN H. STEINHORN, AND JEFFREY R. FINEMAN
}

Department of Pediatrics, Northwestern University, Chicago, Illinois, U.S.A. [S.M.B., E.M.-G., R.H.S.]; Department of Pediatrics [J.M.B., B.O., J.R.F.], Department of Cardiothoracic Surgery [D.M.M., A.J.P., O.R.], University of California, San Francisco, San Francisco, California, U.S.A; Cardiovascular Research Institute, San Francisco, California, U.S.A [J.R.F.]; Department of Pediatrics, SUNY Buffalo, Buffalo, New York, U.S.A. [SL]

\begin{abstract}
Nitric oxide (NO) is an important mediator of pulmonary vascular reactivity, and decreased NO synthase expression has been demonstrated in children with advanced pulmonary hypertension secondary to congenital heart disease and increased pulmonary blood flow. Using aortopulmonary vascular graft placement in the fetal lamb, we have established a unique animal model of pulmonary hypertension with increased pulmonary blood flow. At 4 wk of age, these lambs display an early, selective impairment in agonist-induced NO responses, but an up-regulation of basal NO activity and gene expression. We hypothesized that further exposure to increased flow and/or pressure results in progressive endothelial dysfunction and a subsequent decrease in basal NO production. The objective of this study was to characterize potential later alterations in agonist-induced NO responses and basal NO activity and gene expression induced by $8 \mathrm{wk}$ of increased pulmonary blood flow and pulmonary hypertension. Twenty-two fetal lambs underwent in utero placement of an aortopulmonary vascular graft (shunt), and were studied $8 \mathrm{wk}$ after delivery. Both in vivo and in isolated pulmonary arteries, the pulmonary vasodilating response to endothelium-dependent agents was attenuated in shunted lambs ( $p$ $<0.05$ ), whereas the response to endothelium-independent
\end{abstract}

ABSTRACT

agents was unchanged. The pulmonary vasoconstricting responses to $N \omega$-nitro-L-arginine, and lung tissue endothelial $\mathrm{NO}$ synthase mRNA, endothelial NO synthase protein, NO synthase activity, and $\mathrm{NO}_{\mathrm{X}}$ levels were all unchanged. These data suggest that the increase in basal NO activity demonstrated after $4 \mathrm{wk}$ of increased pulmonary blood flow is lost by $8 \mathrm{wk}$ of age, whereas the attenuation of agonist-induced responses persists. We speculate that the progressive decrease in basal NO activity participates in the development of pulmonary hypertension secondary to increased pulmonary blood flow. (Pediatr Res 52: 233-244, 2002)
ACH, acetylcholine
NO, nitric oxide
sGC, soluble guanylate cyclase
cGMP, guanosine-3',5'-cyclic monophosphate
eNOS, endothelial nitric oxide synthase
NOS, nitric oxide synthase
LNA, $N^{\omega}$-nitro-L-arginine
HSP 90, heat shock protein 90
Flk-1, fetal liver kinase 1

Abbreviations
The development of pulmonary hypertension and its associated increased vascular reactivity commonly accompanies congenital heart disease with increased pulmonary blood flow

Received July 25, 2001; accepted April 16, 2002.

Correspondence and reprint requests: Jeffrey R. Fineman, M.D., University of California, San Francisco, 505 Parnassus Avenue, Box 0106, M-680, San Francisco, CA 94143-0106, U.S.A.; e-mail: jfineman@pedcard.ucsf.edu

Supported by Grants HL61284 (J.R.F.), HL60190 (S.M.B.), and HD398110 (S.M.B.) from the National Institutes of Health; Grants FY99-421 (J.R.F.) and FY00-98 (S.M.B.) from the March of Dimes; and Grant 0051409Z from the American Heart Association, Midwest Affiliate (S.M.B.).

DOI: 10.1023/01.PDR.0000023495.70201.55
(1-3). After birth, the presence of a systemic-to-pulmonary communication results in increased pulmonary blood flow, increased pulmonary arterial pressure, and the progressive development of structural and functional abnormalities of the pulmonary vascular bed. Recent evidence suggests that normal pulmonary vascular reactivity and vascular smooth muscle cell proliferation is regulated by a complex interaction of vasoactive substances that are produced locally by the vascular endothelium (4-7). Endothelial injury secondary to increased pulmonary blood flow and/or pressure disrupts these regulatory mechanisms and is a potential factor in the development of pulmonary hypertension. 
$\mathrm{NO}$ is an endothelium-derived relaxing factor synthesized by the oxidation of the guanidino nitrogen moiety of L-arginine after activation of NOS $(8,9)$. After certain stimuli, such as shear stress and the receptor binding of specific vasodilators (endothelium-dependent vasodilators), NO is synthesized and released from the endothelial cell by the activation of eNOS $(10,11)$. Once released from endothelial cells, NO diffuses into vascular smooth muscle cells and activates sGC, a heterodimer with $\alpha_{1}$ and $\beta_{1}$ subunits, which catalyzes the production of cGMP from guanosine-5'-triphosphate. cGMP induces vascular smooth muscle relaxation through activation of a cGMPdependent protein kinase, although the exact mechanism remains unclear (12-14). Endothelium-derived NO (and the resulting cGMP) is an important mediator of resting pulmonary vascular tone, a modulator of pulmonary vasoconstriction, and an inhibitor of platelet aggregation and smooth muscle mitogenesis $(4,5,15)$.

Several studies demonstrate aberrations in the NO-cGMP cascade in humans with pulmonary hypertension. For example, children with increased pulmonary blood flow secondary to congenital heart disease have selective impairment of endothelium-dependent pulmonary vasodilation (16). In addition, adults with advanced pulmonary hypertension have impaired endothelium-dependent pulmonary vasodilation and decreased eNOS gene expression within pulmonary vascular endothelial cells $(17,18)$. However, the potential role of the NO-cGMP cascade in the early pathogenesis of pulmonary hypertension is uncertain.

To better understand the role of NO in the early pathophysiology of pulmonary hypertension, we established an unique animal model of increased pulmonary blood flow and pulmonary hypertension, using in utero placement of an aortopulmonary vascular graft in the fetal lamb (19). We have previously shown that these shunted lambs have physiologic alterations in $\mathrm{NO}$ activity and gene expression as early as 4 wk of age. For example, shunted lambs display a selective impairment of endothelium-dependent pulmonary vasodilation, suggestive of decreased agonist-induced NO activity $(20,21)$. However, shunted lambs also display an augmented pulmonary vasoconstricting response to LNA (a competitive inhibitor of $\mathrm{NO}$ synthesis,) increased plasma concentrations of cGMP, and increased eNOS protein and mRNA levels, suggestive of increased basal NO activity $(20,22)$.

We hypothesized that further exposure to increased flow and/or pressure results in progressive endothelial dysfunction, and a subsequent decrease in basal NO production. Therefore, the purpose of the present study was to characterize potential later alterations in agonist-induced NO responses and basal NO activity and gene expression induced by increased pulmonary blood flow and pulmonary hypertension. To characterize potential later alterations in agonist-induced NO responses, the responses to endothelium-dependent and -independent vasodilators were studied both in vivo and in fifth-generation pulmonary arteries isolated from 8-wk-old shunted and age-matched control lambs. To determine potential mechanisms for differences in agonist-induced responses, peripheral lung protein levels of caveolin-1 and HSP 90 were determined by Western blot analysis. To characterize potential later alterations in basal
NO activity, the pulmonary vasoconstricting response to LNA was also studied and compared in intact 8-wk-old shunted and age-matched control lambs. In addition, eNOS mRNA levels (RNase protection assays), eNOS protein (determined by Western blot analysis), NOS activity (determined by the conversion of ${ }^{3} \mathrm{H}$-arginine to ${ }^{3} \mathrm{H}$-citrulline), lung tissue $\mathrm{NO}_{\mathrm{X}}$ concentrations (an indirect determinant of NO production), and cGMP concentrations (the second messenger of NO-mediated vasodilation) were studied and compared.

\section{METHODS}

\section{Surgical Preparations and Care}

Ewes. Twenty-two mixed-breed Western pregnant ewes $(136-141 \mathrm{~d}$ gestation, term $=145 \mathrm{~d})$ were operated on under sterile conditions, as previously described (19). Through a left lateral fetal thoracotomy, an 8.0-mm Gore-tex vascular graft ( $\sim 2 \mathrm{~mm}$ length) (W.L. Gore and Associates, Milpitas, CA, U.S.A.) was anastomosed between the ascending aorta and main pulmonary artery of the fetus with 7.0 proline (Ethicon Inc., Somerville, NJ, U.S.A.), using a continuous suture technique, as previously described (19). After recovery from anesthesia, the ewe was returned to the cage with free access to food and water. Antibiotics $(1 \mathrm{~g}$ of cefazolin and $100 \mathrm{mg}$ of gentamicin sulfate) were administered to the ewe during surgery and daily thereafter until $2 \mathrm{~d}$ after spontaneous delivery of the lamb.

Lambs. After spontaneous delivery, antibiotics [1 million units of penicillin $\mathrm{G}$ potassium and $25 \mathrm{mg}$ of gentamicin sulfate intramuscular (i.m.)] were administered for $2 \mathrm{~d}$. The lambs were weighed daily and the respiratory rate and heart rates were obtained. Furosemide $(1 \mathrm{mg} / \mathrm{kg}$ i.m.) was administered daily. Elemental iron (50 mg i.m.) was given weekly. At $8 \mathrm{wk}$ of age, 28 lambs (15 shunted and 13 age-matched controls) were anesthetized with ketamine hydrochloride $(15 \mathrm{mg} / \mathrm{kg}$ i.m.). Under additional local anesthesia with $1 \%$ lidocaine hydrochloride, polyvinyl catheters were placed in an artery and vein of one hind leg. These catheters were advanced to the descending aorta and the inferior vena cava, respectively. The lambs were then anesthetized with ketamine hydrochloride $(\sim 0.3 \mathrm{mg} / \mathrm{kg} / \mathrm{min})$, diazepam $(0.002 \mathrm{mg} / \mathrm{kg} / \mathrm{min})$, and fentanyl citrate $(1.0 \mu \mathrm{g} / \mathrm{kg} / \mathrm{h})$, intubated with a $6.0-7.5 \mathrm{~mm}$ outer diameter endotracheal tube, and mechanically ventilated with a Healthdyne pediatric time-cycled, pressure-limited ventilator (Healthdyne Inc., Marietta, GA, U.S.A.). An i.v. infusion of lactated Ringer's and 5\% dextrose $(75 \mathrm{~mL} / \mathrm{h})$ was begun and continued throughout the study period. Succinylcholine chloride $(2 \mathrm{mg} / \mathrm{kg} / \mathrm{dose})$ was given intermittently for muscle relaxation. Heart rate and systemic blood pressure were monitored continuously to ensure adequate anesthesia. Ventilation with $21 \%$ oxygen was adjusted to maintain a partial pressure of carbon dioxide between 35 and $45 \mathrm{~mm} \mathrm{Hg}$. A midsternotomy incision was performed and the pericardium was incised. Two single-lumen polyurethane catheters were inserted into the left and right atrium, respectively. A double-lumen polyurethane catheter was placed in the main pulmonary artery distal to the vascular graft. An ultrasonic flow probe (Transonics Systems Inc., Ithaca, NY, U.S.A.) was placed around the left pulmonary 
artery to measure left pulmonary blood flow. After a 30-min recovery, blood was obtained from the left and right atria, distal pulmonary artery, right ventricle, and descending aorta for $\mathrm{Hb}$ and oxygen saturation determinations. The midsternotomy incision was then temporarily closed with towel clamps, and the baseline hemodynamic variables were obtained.

Sixteen lambs (nine shunted and seven age-matched controls) then underwent a hemodynamic study as described below. After the last protocol, the lambs were killed by an i.v. injection of pentobarbital sodium (Euthanasia CII, Central City Medical, Union City, CA, U.S.A.) followed by bilateral thoracotomy. Twelve of the lambs (six shunted and six twin controls) were killed without undergoing any hemodynamic study. These lungs were removed and prepared for tissue $\mathrm{NO}_{\mathrm{X}}$ and cGMP concentrations, total NOS activity, Western blot analysis, and RNase protection assays. The remaining 16 lambs (seven shunted and nine controls) were killed by rapid exsanguination through cardiac puncture after induction of adequate anesthesia with pentobarbital sodium $(30 \mathrm{mg} / \mathrm{kg}$ i.v. $)$. The lungs were than removed and used for the isolated vessel protocols described below.

All protocols and procedures were approved by the Committee on Animal Research of the University of California, San Francisco, and the State University of New York, Buffalo, NY. All animals were euthanized using appropriate methods as described in the National Institutes of Health Guidelines for the Care and Use of Laboratory Animals.

\section{Experimental Protocols}

In vivo agonist-induced NO-dependent responses. The responses to vasodilating agents may be dependent on the resting tone of the vascular bed studied (23). Therefore, vasodilator responses in control lambs were studied during an i.v. infusion of 9,11 , dideoxy-11A, $9 \alpha$ epoxymethano-prostaglandin $\mathrm{F}_{2 \alpha}$ (U46619, a thromboxane $A_{2}$ mimic), and the dose was titrated to induce a similar degree of pulmonary hypertension as resting shunted lambs. The responses to ACH and inhaled NO were also determined in control lambs at rest. Shunted lambs were studied at rest with the vascular graft open. In addition, because the shunted lambs had significantly greater pulmonary blood flow and lower pulmonary vascular resistance than control lambs, shunted lambs were also studied after the vascular graft was closed, when pulmonary blood flow and pulmonary vascular resistance were similar to controls.

Control lambs. After a 45-min recovery period from surgery, baseline measurements of the hemodynamic variables (pulmonary and systemic arterial pressure, heart rate, left pulmonary blood flow, left and right atrial pressures) and systemic arterial blood gases and $\mathrm{pH}$ were measured. An infusion of U46619 was then begun into the inferior vena cava. The dose $(\sim 1-2 \mu \mathrm{g} / \mathrm{kg} / \mathrm{min})$ was titrated to increase mean pulmonary arterial pressure to a similar value as shunted lambs ( 2-3 times baseline). After 15 min of steady-state pulmonary hypertension, all variables were measured. ACH $(1.0 \mu \mathrm{g} / \mathrm{kg})$ or inhaled NO (40 ppm) was then administered in random order. $\mathrm{ACH}$ was injected into the pulmonary artery over $2 \mathrm{~min}$; inhaled NO was delivered through the ventilator for $15 \mathrm{~min}$.
The hemodynamic variables were measured continuously and systemic arterial blood gases and $\mathrm{pH}$ were obtained when a new steady state was achieved. At least 20 min were allowed for the hemodynamic variables to return to preinjection values. All measurements were then repeated and the other agent was given. After recovery from the last agent, the infusion of U46619 was stopped. After a 60-min recovery period, baseline measurements were again obtained, $\mathrm{ACH}$ and inhaled $\mathrm{NO}$ were administered, and the hemodynamic variables were measured as described above.

Shunted lambs. After a 45-min recovery period from surgery, baseline measurements of the hemodynamic variables and systemic arterial blood gases and $\mathrm{pH}$ were measured. $\mathrm{ACH}$ and inhaled NO were then administered as described above. The vascular graft was then closed. After a 60-min recovery, the responses to $\mathrm{ACH}$ and inhaled $\mathrm{NO}$ were repeated.

\section{Basal NO Activity}

After a 60-min recovery period, baseline measurements of the hemodynamic variables and systemic arterial blood gases and $\mathrm{pH}$ were again obtained in six of the resting control lambs and eight of the shunted lambs with the graft open. LNA (5 $\mathrm{mg} / \mathrm{kg}$ ) was then injected into the pulmonary artery, and the hemodynamic variables were measured as described above.

To indirectly assess basal NO activity, tissue concentrations of NO metabolites $\left(\mathrm{NO}_{\mathrm{X}}\right)$, tissue concentrations of cGMP (the second messenger to NO-mediated vasodilation), and total NOS activity were also determined in six shunted lambs and their twin controls, as described below. In addition, eNOS protein levels were determined by Western blot analysis and eNOS mRNA levels were determined by RNase protection assays as described below.

\section{Measurements}

Pulmonary and systemic arterial and right and left atrial pressures were measured using Sorenson Neonatal Transducers (Abbott Critical Care Systems, Chicago, IL, U.S.A.). Mean pressures were obtained by electrical integration. Heart rate was measured by a cardiotachometer triggered from the phasic systemic arterial pressure pulse wave. Left pulmonary blood flow was measured on an ultrasonic flow meter (Transonic Systems). All hemodynamic variables were recorded continuously on a Gould multichannel electrostatic recorder (Gould, Cleveland, OH, U.S.A.). Systemic arterial blood gases and $\mathrm{pH}$ were measured on a Radiometer ABL5 pH/blood gas analyzer (Radiometer, Copenhagen, Denmark). Hb concentration and oxygen saturation were measured by a hemoximeter (model 270, Bayer Diagnostics, Tarrytown, NY, U.S.A.). The ratio of pulmonary to systemic blood flow (Qp/Qs) was calculated using the Fick equation. Pulmonary vascular resistance was calculated using standard formulas.

\section{Drug Preparation}

ACH chloride (Iolab Corporation, Claremont, CA, U.S.A.) was diluted in sterile $0.9 \%$ saline. Inhaled NO (40 ppm) was delivered in nitrogen into the inspiratory limb of the ventilator 
(Inovent, Ohmeda PPD, Liberty Corner, NJ, U.S.A.). The inspired concentrations of $\mathrm{NO}$ and nitrogen dioxide were continuously quantified by electrochemical methodology (Inovent, Ohmeda PPD). LNA (Sigma Chemical, St. Louis, MO, U.S.A.) was dissolved in sterile distilled water. U46619 (Sigma Chemical) dissolved in $95 \%$ ethanol was stored at $-20^{\circ} \mathrm{C}$. Immediately before the study, $100 \mu \mathrm{g}$ was dissolved in $20 \mathrm{~mL}$ of $0.9 \%$ saline. All solutions were prepared on the day of the study.

\section{Isolated Vessel Agonist-Induced NO-Dependent Responses}

Seven shunted lambs (6-8 wk old) and nine age-matched controls were killed as previously described (21). For these studies, the heart and lungs were removed en bloc from the thorax immediately after death and placed in Krebs-Ringer solution (in mM: $118 \mathrm{NaCl}, 4.7 \mathrm{KCl}, 2.5 \mathrm{CaCl}_{2}, 1.2 \mathrm{MgSO}_{4}$, $1.2 \mathrm{KH}_{2} \mathrm{PO}_{4}, 25.5 \mathrm{NaHCO}_{3}, 5.6$ glucose, and 0.026 calcium disodium EDTA). Fifth-generation intralobar pulmonary arteries with inside diameters of $0.5-1.5 \mathrm{~mm}$ were isolated, dissected with care to preserve the integrity of the endothelium, and cut into rings $\sim 2-3 \mathrm{~mm}$ long and $1-3 \mathrm{mg}$ in weight. Vessel rings were mounted on stainless steel hooks and placed in water-jacketed chambers. Tissues were bathed with $6 \mathrm{~mL}$ of Krebs-Ringer solution, which was maintained at $37^{\circ} \mathrm{C}$ and aerated with a gas mixture of $94 \% \mathrm{O}_{2}$ and $6 \% \mathrm{CO}_{2}$ to maintain $\mathrm{pH} 7.40, \mathrm{pCO}_{2} \sim 38 \mathrm{~mm} \mathrm{Hg}$, and $\mathrm{pO}_{2}>500 \mathrm{~mm} \mathrm{Hg}$. A continuous recording of isometric force generation was obtained by tying each vessel ring to a force-displacement transducer (Statham UC 2, Statham Instruments, Hato Rey, Puerto Rico) that was connected to an oscillographic recorder. Once mounted, the vessel rings were allowed to equilibrate for 20 min in the bathing solution. A micrometer was then used to stretch the tissues repeatedly in small increments over the next 45 min until resting tone remained stable at a passive tension of $1.0 \mathrm{~g}$ for control arteries and $1.2 \mathrm{~g}$ for arteries from hypertensive lambs. Preliminary experiments determined that this was the optimal length for generation of active tone in response to exogenous norepinephrine.

\section{Isolated Vessel Protocols}

The following pharmacological agents were used: indomethacin, DL-propranolol, LNA, L-norepinephrine hydrochloride, calcium ionophore A-23187, and $S$-nitroso- $N$-acetyl penicillamine (SNAP). All drugs were purchased from Sigma Chemical and Aldrich Chemical (Milwaukee, WI, U.S.A.). LNA was dissolved directly in Krebs-Ringer solution, and indomethacin was dissolved in ethanol. All other drugs were dissolved in distilled water. At the concentrations used in these experiments, ethanol did not alter the preexisting tone of pulmonary arteries or veins. Vessels were pretreated with indomethacin $\left(10^{-5} \mathrm{M}\right)$ to prevent the formation of vasoactive prostaglandins and propranolol $\left(10^{-6} \mathrm{M}\right)$ to block the $\beta$-adrenergic receptors. In protocols involving SNAP-mediated relaxation, the vessels were also pretreated with $\operatorname{LNA}\left(10^{-3} \mathrm{M}\right)$ to inhibit NOS. All experiments were performed in a darkened room, as LNA is sensitive to light.
The vessels were first constricted with norepinephrine (NE) to produce half-maximal constriction. This $\mathrm{EC}_{50}$ concentration of $\mathrm{NE}$ was determined from preliminary studies in which cumulative concentration-response curves for $\mathrm{NE}\left(10^{-8}-10^{-5}\right.$ $\mathrm{M})$ were developed in pulmonary arteries and veins. Once the response to NE had reached a steady level, cumulative concentration response curves to A-23187 and SNAP were obtained by increasing the bath concentration of these agents in successive steps. The next concentration was added only when the response to the prior concentration had reached a plateau. Vessel rings were used for one experimental protocol and then discarded. In all experiments, $n$ represents the number of animals from which vessel rings were studied. Wet tissue weights were obtained at the end of each experiment after the rings were blotted dry on gauze pads. The force of contraction was normalized by the weight of each ring and is expressed as grams per gram of tissue $(\mathrm{g} / \mathrm{g})$.

\section{Tissue Preparation}

The heart and lungs were removed en bloc. The lungs were dissected with care to preserve the integrity of the vascular endothelium. Two- to three-gram sections from each lobe of the lung were removed. These tissues were snap-frozen in liquid nitrogen, and stored at $-70^{\circ} \mathrm{C}$ until used. Isolated pulmonary arteries for also snap-frozen in liquid nitrogen, and stored at $-70^{\circ} \mathrm{C}$ until used for biochemical and molecular analysis.

For RNA isolation, the snap-frozen lung tissue was pulverized, then briefly homogenized in $4 \mathrm{M}$ guanidinium isothiocyanate. Total RNA was extracted with acid phenol and precipitated in isopropanol. For protein isolation, the snap-frozen lung tissue was allowed to thaw on ice, and then homogenized using a Tissuemizer $(2 \times 15 \mathrm{~s}$ at $80 \%$ power $)$ at $4 \mathrm{vol} / \mathrm{wet}$ weight of Triton lysis buffer [ $20 \mathrm{mM}$ Tris- $\mathrm{HCl}(\mathrm{pH} 7.6), 0.5 \%$ Triton X-100, and $20 \%$ glycerol] supplemented with protease inhibitors. The supernatant was removed for protein determination and Western blot analysis.

\section{RNAse Protection Assays}

RNAse protection assays were performed as previously described (22). Studies were done on total RNA prepared from control and shunt lung, using the antisense radiolabeled cRNA eNOS probes. Antisense radiolabeled, single-stranded ovine RNA probes were hybridized overnight at $42^{\circ} \mathrm{C}$ with total RNA isolated from control and shunt lung $(50 \mu \mathrm{g})$ in $80 \%$ formamide, $50 \mathrm{mM}$ piperazine diethanesulfonic acid ( $\mathrm{pH} 6.4)$, $0.4 \mathrm{M} \mathrm{NaCl}$, and $1 \mathrm{mM}$ EDTA. Single-stranded RNA was digested with an RNAse A/T1 mixture (Ambion, Austin, TX, U.S.A.) for $1 \mathrm{~h}$ at $37^{\circ} \mathrm{C}$. After phenol/ $\mathrm{CHCl}_{3}$ extraction and ethanol precipitation, the protected fragments were analyzed by electrophoresis on a $6 \%$ denaturing polyacrylamide gel. Also included was a probe for $18 \mathrm{~S}$ to serve as a control for the amount of input total RNA and the recovery of protected probe fragments. 


\section{Preparation of Protein Extracts and Western Blot Analysis}

Lung protein extracts were prepared as above. Supernatants were quantitated for protein concentration using the Bradford reagent (Bio-Rad, Richmond, CA, U.S.A.), then used for Western blot analysis. Western blot analysis was performed as previously described (22). Briefly, lung protein extracts (100 $\mu \mathrm{g})$ were separated on SDS-polyacrylamide gels $(7.5 \%$ for eNOS, and HSP 90, 4-20\% gradient gels for caveolin-1, and $12 \%$ for Flk-1), and either electrophoretically transferred to Hybond-PVDF membranes (Amersham Pharmacia Biotech, Arlington Heights, IL, U.S.A.) or stained with Coomassie brilliant blue to normalize for any differences in protein loading. The membranes were blocked with $5 \%$ nonfat dry milk in Tris-buffered saline containing $0.1 \%$ Tween to limit nonspecific binding. After blocking, the membranes were washed with Tris-buffered saline, then incubated at room temperature with the appropriate antibody. Specific MAb for eNOS (1:2500 dilution), HSP 90 (1:1000 dilution), and caveolin-1 (1:1000) were obtained from Transduction Laboratories, Lexington, KY, U.S.A. For the Flk-1 Western analysis, a primary Flk-1 antibody (Santa Cruz Laboratories, Santa Cruz, CA, U.S.A.) was used. Membranes were washed, then incubated at room temperature with an anti-mouse IgG-horseradish peroxidase conjugate (1:1000 dilution). After washing, chemiluminescence (Pierce Laboratories, Rockford, IL) was used to detect the protein bands of interest. Multiple exposure times were used to ensure that the bands of interest were within the dynamic range of the x-ray film used.

\section{Assay for NOS Activity}

This assay was performed using the conversion of ${ }^{3} \mathrm{H}$ arginine to ${ }^{3} \mathrm{H}$-citrulline as a measure of NOS activity essentially as described by Bush et al. (8). Briefly, lung tissues (peripheral lung and isolated pulmonary arteries) were homogenized in NOS assay buffer (50 mM Tris-HCl, $\mathrm{pH} 7.5$, containing $0.1 \mathrm{mM}$ EDTA and $0.1 \mathrm{mM}$ EGTA) with a protease inhibitor cocktail. Enzyme reactions were carried out at $37^{\circ} \mathrm{C}$ in the presence of total lung protein extracts $(500 \mu \mathrm{g}), 1 \mathrm{mM}$ NADPH, $14 \mu \mathrm{M}$ tetrahydrobiopterin, $100 \mu \mathrm{M}$ flavin adenine dinucleotide, $1 \mathrm{mM} \mathrm{MgCl}_{2}, 5 \mu \mathrm{M}$ unlabeled L-arginine, $15 \mathrm{nM}$ ${ }^{3} \mathrm{H}$-arginine, calmodulin ( 25 units), and $5 \mathrm{mM}$ calcium to produce conditions that drive the reaction at maximal velocity. Duplicate assays were run in the presence of the NOS inhibitor L-NAME. Assays were incubated for $60 \mathrm{~min}$ at $37^{\circ} \mathrm{C}$ such that no more than $20 \%$ of the ${ }^{3} \mathrm{H}$-arginine was metabolized, to insure that the substrate was not limiting. The reactions were stopped by the addition of iced stop buffer $(20 \mathrm{mM}$ sodium

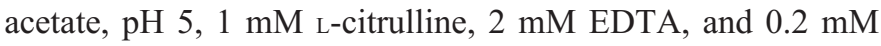
EGTA) then applied to columns containing $1 \mathrm{~mL}$ of Dowex AG50W-X8 resin, $\mathrm{Na}^{+}$form, preequilibrated with $1 \mathrm{~N} \mathrm{NaOH}$. ${ }^{3} \mathrm{H}$-citrulline was then quantitated by scintillation counting.

\section{$\mathrm{NO}_{\mathbf{X}}$ Determinations}

Lung tissue was homogenized in $6 \%$ trichloroacetic acid (TCA) at $4^{\circ} \mathrm{C}$ to give a $10 \%$ weight to volume homogenate, and centrifuged at $3000 \mathrm{rpm}$ for $15 \mathrm{~min}$ at $4^{\circ} \mathrm{C}$. The supernate was recovered and used immediately for analysis. In solution, NO reacts with molecular oxygen to form nitrite, and with oxyhemoglobin and superoxide anion to form nitrate. The nitrite and nitrate were reduced using vanadium (III) and hydrochloric acid at $90^{\circ} \mathrm{C}$. NO was then purged from solution resulting in a peak of NO. Therefore, this value represents a combination of total $\mathrm{NO}$, nitrite, and nitrate $\left(\mathrm{NO}_{\mathrm{X}}\right)$. This peak was then detected by chemiluminescence (NOA 280, Sievers Instruments, Boulder, CO, U.S.A.). The detection limit is 1 $\mathrm{nM} / \mathrm{mL}$ of nitrate.

\section{cGMP Determinations}

Tissue was homogenized in $6 \%$ TCA at $4{ }^{\circ} \mathrm{C}$ to give a $10 \%$ weight-to-volume homogenate and centrifuged at $2000 \mathrm{rev} /$ $\min$ for $15 \mathrm{~min}$ at $4^{\circ} \mathrm{C}$. The supernate was recovered and washed four times with 5 volumes of water-saturated diethyl ether. Aqueous extracts were then lyophilized and the dried pellet resuspended in assay buffer before analysis. The samples were assayed with a cGMP $\left[{ }^{125} \mathrm{I}\right]$ RIA kit (Amersham plc, Little Chalfont, Buckinghamshire, U.K.) according to manufacturer's instructions. Cross-reactivity for other nucleotides is $<0.001$.

\section{Statistical Analysis}

The means \pm SD were calculated for the baseline hemodynamic variables, systemic arterial blood gases and $\mathrm{pH}$, tissue $[\mathrm{SCAP}] \mathrm{NO}[\mathrm{R}]_{\mathrm{X}}$ and cGMP concentrations, and NOS activity. The general hemodynamic variables, systemic arterial blood gases and $\mathrm{pH}$, tissue $[\mathrm{SCAP}] \mathrm{NO}[\mathrm{R}]_{\mathrm{X}}$ and cGMP concentrations, and tissue NOS activity were compared between study groups by the unpaired $t$ test. The effects of each vasoactive agent were compared with their previous steady-state condition by the paired $t$ test using the Bonferroni correction when necessary. The percentage change in pulmonary vascular resistance induced by these agents was compared between study groups by the unpaired $t$ test or ANOVA for repeated measures with multiple comparison testing. Data from isolated vessel protocols are expressed as mean $\pm \mathrm{SE}$. Individual data points on concentration-response curves were also compared using unpaired $t$ test.

Quantitation of autoradiographic results was performed by scanning (Hewlett Packard SCA Jet IICX, Hewlett Packard, Palo Alto, CA, U.S.A.) the bands of interest into an image editing software program (Adobe Photoshop, Adobe Systems, Mountain View, CA, U.S.A.). Band intensities from RNase protection assays and Western blot analysis were analyzed densitometrically on a Macintosh computer (model 9500, Apple Computer, Cupertino, CA, U.S.A.) using the public domain NIH Image program (developed at the National Institutes of Health and available on the Internet at http://rsb.info.nih.gov/ nih-image). For RNase protection assays, to control for the amount of input RNA and the recovery of protected probe fragments, the mRNA signal of interest was normalized to the corresponding $18 \mathrm{~S}$ signal for each lane. Results from control lungs were assigned the value of 1 (relative mRNA). For Western blot analysis, to insure equal protein loading, dupli- 
cate polyacrylamide gels were run. One was stained with Coomassie blue. To control for the number of endothelial cells in the lung, the eNOS protein signal was normalized to Flk-1. The mean $\pm \mathrm{SD}$ was calculated for the relative mRNA and the relative protein. Comparisons between control and shunted lambs were made by the unpaired $t$ test. A $p<0.05$ was considered statistically significant.

\section{RESULTS}

At $8 \mathrm{wk}$ of age, shunted lambs weighed significantly less than controls ( $21.6 \pm 6.8 \mathrm{~kg}$ versus $25.7 \pm 4.2 \mathrm{~kg}, p<0.05)$. All shunted lambs had an audible continuous murmur and an increase in oxygen saturation between the right ventricle and distal pulmonary artery. The ratio of pulmonary to systemic blood flow (Qp/Qs) was $3.3 \pm 0.9$. Mean pulmonary arterial pressure was increased $(28.3 \pm 13.5 \mathrm{~mm} \mathrm{Hg}$ versus $16.8 \pm 3.8$ $\mathrm{mm} \mathrm{Hg}, p<0.05)$ to $45 \%$ of systemic values. This was associated with an increase in left pulmonary blood flow, left atrial pressure, and heart rate $(p<0.05)$. The calculated left pulmonary vascular resistance was decreased $(p<0.05)$. Mean systemic arterial pressure, right atrial pressure, systemic arterial blood gases, and $\mathrm{pH}$ were not significantly different between the two groups (Table 1).

\section{Agonist-Induced NO-Dependent Responses}

Control lambs. During steady-state pulmonary hypertension induced by the infusion of U46619, the intrapulmonary injection of ACH decreased mean pulmonary arterial pressure, left pulmonary vascular resistance, and mean systemic arterial pressure $(p<0.05)$. Left pulmonary blood flow increased $(p<$ 0.05 ). Heart rate, left and right atrial pressure, and systemic arterial blood gases and $\mathrm{pH}$ were unchanged. Inhaled NO decreased mean pulmonary arterial pressure and left pulmonary vascular resistance, and increased partial pressure of $\mathrm{O}_{2}$ (from $56.5 \pm 8.7$ to $84.3 \pm 17.5 \mathrm{~mm} \mathrm{Hg}, p<0.05$ ). Left pulmonary blood flow, mean systemic arterial pressure, heart rate, left and right atrial pressure, and systemic arterial partial pressure of $\mathrm{CO}_{2}$ and $\mathrm{pH}$ were unchanged (Table 2). In resting

Table 1. General hemodynamics

\begin{tabular}{lcc}
\hline & Control lambs & Shunted lambs \\
\hline Age (d) & $64.5 \pm 7.7$ & $65.3 \pm 7.3$ \\
Weight (kg) & $25.7 \pm 4.2$ & $21.6 \pm 6.8^{*}$ \\
Pulmonary arterial pressure (PAP) & $18.0 \pm 5.6$ & $28.3 \pm 13.5^{*}$ \\
$\quad$ (mm Hg) & & \\
Systemic arterial pressure (SAP) & $73.5 \pm 11.6$ & $65.7 \pm 15.1$ \\
$\quad$ (mm Hg) & $0.26 \pm 0.11$ & $0.45 \pm 0.19^{*}$ \\
PAP/SAP & $0.339 \pm 0.10$ & $0.159 \pm 0.05^{*}$ \\
Left pulmonary vascular resistance & & \\
$\quad$ (mm Hg/mL/min/kg) & $32.9 \pm 4.1$ & $105.0 \pm 27.9^{*}$ \\
Left pulmonary blood flow & & \\
$\quad$ (mL/kg/min) & $131.5 \pm 17.3$ & $152.0 \pm 13.2^{*}$ \\
Heart rate (beats/min) & $5.3 \pm 1.3$ & $11.9 \pm 6.7^{*}$ \\
Left atrial pressure (mm Hg) & $6.0 \pm 2.4$ & $5.2 \pm 1.7$ \\
Right atrial pressure (mm Hg) & 1.00 & $3.34 \pm 0.9^{*}$ \\
Qp/Qs &
\end{tabular}

Values are mean $\pm \mathrm{SD}, n=6$ shunt lambs and their twin controls. Values in shunted lambs were obtained before closure of the vascular graft.

$* p<0.05$ vs control lambs. control lambs, the intrapulmonary injection of $\mathrm{ACH}$ decreased left pulmonary vascular resistance (from $0.280 \pm 0.05$ to 0.245 $\pm 0.08 \mathrm{~mm} \mathrm{Hg} / \mathrm{mL} / \mathrm{kg} / \mathrm{min}, p<0.05)$ and mean systemic arterial pressure (from $71.3 \pm 7.8$ to $47.2 \pm 9.6 \mathrm{~mm} \mathrm{Hg}, p<$ $0.05)$. Left pulmonary blood flow increased from $35.6 \pm 5.3$ to $38.8 \pm 6.1 \mathrm{~mL} / \mathrm{kg} / \mathrm{min},(p<0.05)$. Mean pulmonary arterial pressure, heart rate, and left and right atrial pressure were unchanged. Inhaled NO decreased mean pulmonary arterial pressure (from $18.4 \pm 4.3$ to $16.1 \pm 3.3 \mathrm{~mm} \mathrm{Hg}, p<0.05$ ) and left pulmonary vascular resistance (from $0.280 \pm 0.05$ to 0.245 $\pm 0.08 \mathrm{~mm} \mathrm{Hg} / \mathrm{mL} / \mathrm{kg} / \mathrm{min}, p<0.05$ ). Left pulmonary blood flow, mean systemic arterial pressure, heart rate, and left and right atrial pressure were unchanged.

Shunted lambs. In shunted lambs with the vascular graft open, the intrapulmonary injection of $\mathrm{ACH}$ did not change mean pulmonary arterial pressure, left pulmonary blood flow, heart rate, left and right atrial pressures and systemic arterial blood gases and $\mathrm{pH}$. Left pulmonary vascular resistance increased, and mean systemic arterial pressure decreased $(p<$ 0.05 ). Inhaled NO decreased mean pulmonary arterial pressure and left pulmonary vascular resistance $(p<0.05)$. Left pulmonary blood flow, mean systemic arterial pressure, heart rate, left and right atrial pressures and systemic arterial blood gases and $\mathrm{pH}$ were unchanged (Table 3 ). In shunted lambs with the vascular graft closed, the intrapulmonary injection of $\mathrm{ACH}$ did not change mean pulmonary arterial pressure, left pulmonary blood flow, left pulmonary vascular resistance, heart rate, and left and right atrial pressures. Mean systemic arterial pressure decreased from $86.6 \pm 20.4$ to $60.3 \pm 14.2 \mathrm{~mm} \mathrm{Hg},(p<$ $0.05)$. Inhaled NO decreased mean pulmonary arterial pressure (from $20.7 \pm 9.1$ to $16.3 \pm 7.2 \mathrm{~mm} \mathrm{Hg}, p<0.05$ ) and left pulmonary vascular resistance (from $0.267 \pm 0.19$ to $0.198 \pm$ $0.15 \mathrm{~mm} \mathrm{Hg} / \mathrm{mL} / \mathrm{kg} / \mathrm{min}, p<0.05$ ). Left pulmonary blood flow, mean systemic arterial pressure, heart rate, and left and right atrial pressures were unchanged.

The percent decrease in left pulmonary vascular resistance induced by the injection of $\mathrm{ACH}$ (an endothelium-dependent vasodilator) was greater in control lambs than in shunted lambs $(p<0.05)$. However, the response of inhaled NO (an endothelium-independent vasodilator) was similar in both groups (Fig. 1).

\section{Isolated Vessel Agonist-Induced NO-Dependent Responses}

Relaxations to A-23187 were used to test endotheliumdependent relaxation. Figure $2 A$ shows that pulmonary arteries isolated from shunted lambs relaxed significantly less to $3 \times$ $10^{-7}$ M A-23187 than arteries isolated from control lamb (19.6 \pm 8 versus $53.6 \pm 10 \%, p<0.05$ ). Pulmonary arteries from both control and shunted lambs relaxed similarly and completely to endothelium-independent NO donor SNAP (Fig. 2B).

\section{Basal NO Activity}

In control and shunted lambs, the intrapulmonary infusion of LNA increased mean pulmonary arterial pressure, left pulmonary vascular resistance, and mean systemic arterial pressure ( $p$ $<0.05$ ). Left pulmonary blood flow, heart rate, left and right 
Table 2. The effects of vasoactive agents in control lambs

\begin{tabular}{|c|c|c|c|c|c|c|}
\hline & Pre-ACH & $\mathrm{ACH}$ & Pre-NO & Inhaled NO & Pre-LNA & LNA \\
\hline Mean pulmonary arterial pressure $(\mathrm{mm} \mathrm{Hg})$ & $32.6 \pm 3.9$ & $29.9 \pm 4.1^{*}$ & $32.8 \pm 3.9$ & $25.4 \pm 3.4^{*}$ & $16.8 \pm 2.3$ & $19.8 \pm 4.4^{*}$ \\
\hline $\begin{array}{l}\text { Left pulmonary vascular resistance (mm } \\
\mathrm{Hg} / \mathrm{mL} / \mathrm{kg} / \mathrm{min})\end{array}$ & $0.724 \pm 0.25$ & $0.504 \pm 0.18^{*}$ & $0.749 \pm 0.28$ & $0.549 \pm 0.22 *$ & $0.249 \pm 0.06$ & $0.316 \pm 0.12 *$ \\
\hline Mean systemic arterial pressure $(\mathrm{mm} \mathrm{Hg})$ & $99.3 \pm 20.2$ & $64.7 \pm 18.2 *$ & $100.3 \pm 16.4$ & $102.0 \pm 17.6$ & $61.0 \pm 24.2$ & $76.8 \pm 29.4^{*}$ \\
\hline Heart rate (beats/min) & $151.3 \pm 25.6$ & $153.4 \pm 30.0$ & $146.0 \pm 24.1$ & $142.9 \pm 26.2$ & $125.8 \pm 12.9$ & $136.8 \pm 20.8$ \\
\hline Left atrial pressure (mm Hg) & $8.3 \pm 2.9$ & $9.2 \pm 3.1$ & $8.4 \pm 1.9$ & $8.9 \pm 1.7$ & $8.3 \pm 1.5$ & $8.5 \pm 1.6$ \\
\hline
\end{tabular}

Values are mean $\pm \mathrm{SD}, * p<0.05 v$ s previous column. $n=7$ control lambs for ACH and inhaled NO; $n=6$ for LNA.

$\mathrm{ACH}$ and inhaled $\mathrm{NO}$ responses were obtained during U46619-induced pulmonary hypertension; $\mathrm{N}^{\omega}$-nitro-L-arginine LNA responses were obtained at rest.

Table 3. The effects of vasoactive agents in shunted lambs

\begin{tabular}{|c|c|c|c|c|c|c|}
\hline & Pre-ACH & $\mathrm{ACH}$ & Pre-NO & Inhaled NO & Pre-LNA & LNA \\
\hline Mean pulmonary arterial pressure $(\mathrm{mm} \mathrm{Hg}$ ) & $24.5 \pm 7.9$ & $25.3 \pm 7.4$ & $25.7 \pm 8.3$ & $22.8 \pm 7.2^{*}$ & $27.1 \pm 9.4$ & $32.3 \pm 15.4$ \\
\hline $\begin{array}{l}\text { Left pulmonary vascular resistance (mm } \\
\mathrm{Hg} / \mathrm{mL} / \mathrm{kg} / \mathrm{min} \text { ) }\end{array}$ & $0.130 \pm 0.05$ & $0.146 \pm 0.06^{*}$ & $0.123 \pm 0.06$ & $0.099 \pm 0.05^{*}$ & $0.132 \pm 0.06$ & $0.163 \pm 0.10$ \\
\hline Mean systemic arterial pressure (mm Hg) & $62.6 \pm 13.5$ & $47.0 \pm 8.1^{*}$ & $68.8 \pm 13.4$ & $65.9 \pm 12.7$ & $62.68 \pm 13.4$ & $75.6 \pm 12.7$ \\
\hline Heart rate (beats/min) & $142.3 \pm 24.9$ & $144.4 \pm 23.2$ & $147.8 \pm 22.3$ & $143.4 \pm 24.3$ & $138.8 \pm 12.6$ & $140.7 \pm 11.1$ \\
\hline Left atrial pressure $(\mathrm{mm} \mathrm{Hg})$ & $9.2 \pm 4.9$ & $8.3 \pm 4.2$ & $10.1 \pm 3.7$ & $10.4 \pm 4.5$ & $10.1 \pm 4.1$ & $10.6 \pm 5.1$ \\
\hline
\end{tabular}

Values are mean $\pm \mathrm{SD}, * p<0.05$ vs previous column. $n=9$ shunted lambs.

Responses were obtained at rest with the vascular graft open.

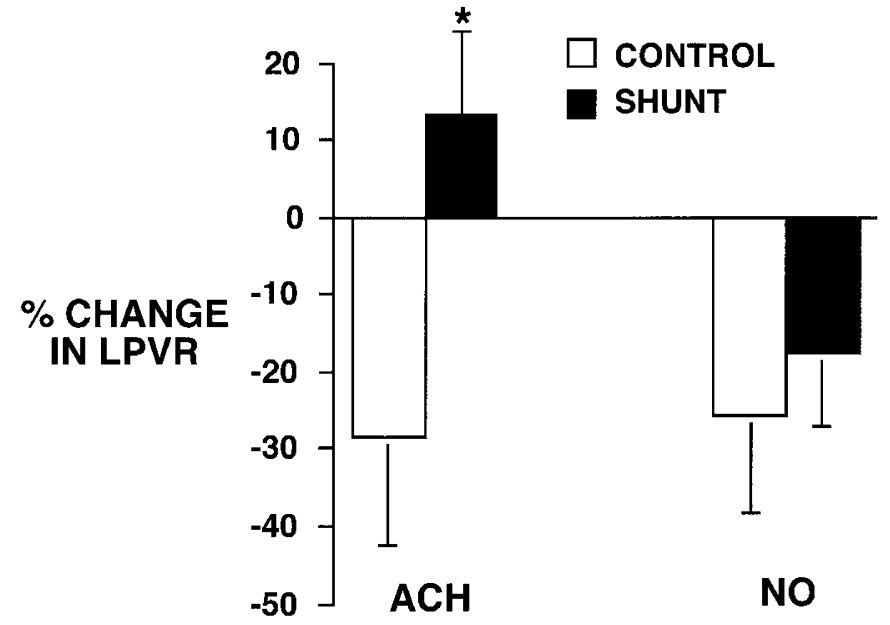

Figure 1. In shunted lambs, the decrease in left pulmonary vascular resistance $(P V R)$ in response to $\mathrm{ACH}$ (an endothelium-dependent vasodilator) is attenuated, but the response to inhaled NO (an endothelium-independent vasodilator) is not. Values are mean $\pm \mathrm{SD}$ for seven control lambs during U46619-induced pulmonary hypertension and nine shunted lambs with the vascular graft open. $* p<0.05$ vs control lambs.

atrial pressures, and systemic arterial blood gases and $\mathrm{pH}$ were unchanged (Tables 2 and 3). The percent increase in left pulmonary vascular resistance induced by the injection of LNA was similar in resting control and shunted lambs (Fig. 3).

RNase protection assays demonstrated no differences in eNOS mRNA expression in peripheral lung obtained from shunt and twin control lambs (Fig. 4). Western blot analysis also demonstrated no differences in eNOS protein levels in peripheral lung obtained from shunt and twin control lambs (Fig. 5). These values were identical when normalized for endothelial cell number with Flk-1 protein values (data not shown). In addition, no differences in eNOS protein levels were demonstrated in isolated fifth-generation pulmonary arteries obtained from control and shunted lambs (Fig. 5B).

Total peripheral lung NOS activity $[0.204 \pm 0.15$ versus $0.150 \pm 0.10 \mathrm{pmol} / \mathrm{min} / \mathrm{mg}$ (Fig. $6 A$ ) , and total NOS activity in isolated fifth-generation pulmonary arteries $[0.468 \pm 0.11$ versus $0.419 \pm 0.18 \mathrm{pmol} / \mathrm{min} / \mathrm{mg}$ (Fig. 6B)] were similar in shunted and twin control lambs. To further explore potential regulators of eNOS activity, we determined protein levels of HSP 90, a known positive regulator of eNOS activity, and caveolin-1, a negative regulator of eNOS activity (24). We found no change in the protein levels of HSP 90 between control and shunted lambs, but decreased protein levels of caveolin-1 in shunted lambs $(p<0.05)$ (Fig. 7). Because the decrease in caveolin-1 protein levels could potentially alter basal eNOS activity, we determined peripheral lung tissue $\mathrm{NO}_{\mathrm{X}}$ concentrations, an indirect determination of $\mathrm{NO}$ production. As seen in Figure 8, tissue $\mathrm{NO}_{\mathrm{X}}$ concentrations $(4.7 \pm 0.9$ versus $4.2 \pm 1.9 \mu \mathrm{mol} / \mathrm{mL}$, Fig. 8 ) were similar in both groups.

Lastly, peripheral lung tissue cGMP concentrations, the second messenger of NO-mediated vasodilation, were increased by $187 \%$ in shunted lambs ( $p<0.05$, Fig. 9).

\section{DISCUSSION}

Endothelial injury and the resulting aberration in endothelial function have been implicated in the pathophysiology of pulmonary hypertension and its associated increased vascular reactivity. For example, lungs from adults with advanced pulmonary vascular disease display impaired endotheliumdependent pulmonary relaxation, and decreased expression of eNOS $(17,18)$. In addition, earlier endothelial dysfunction, as displayed by histologic abnormalities and impairment of endothelium-dependent pulmonary vasodilation has also been described in children with increased pulmonary blood flow 

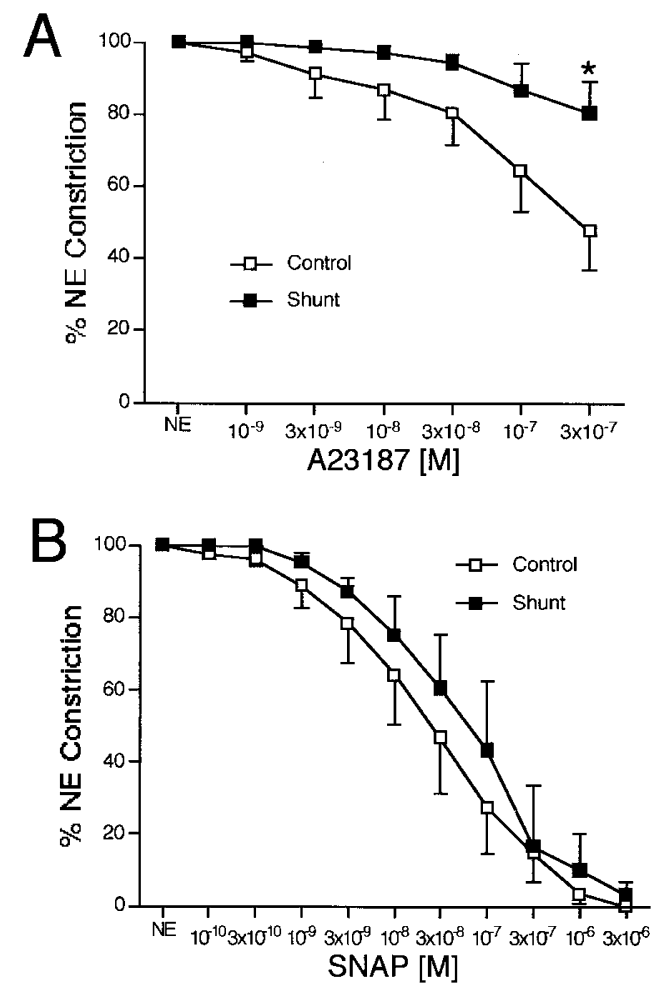

Figure 2. Cumulative concentration-response curves for the receptorindependent NOS agonist A-23187 $(A)$ and NO donor SNAP $(B)$. Increasing concentrations of A-23187 relax pulmonary arteries $(P A)$ isolated from control lambs more significantly than PA from shunted lambs. No differences were observed in PA response to increasing concentrations of SNAP. Relaxations are expressed as percentage of plateau norepinephrine $(N E)$ constriction $(100 \%)$. Data are means $\pm \mathrm{SE} ;{ }^{*} p<0.05 v s$ control.

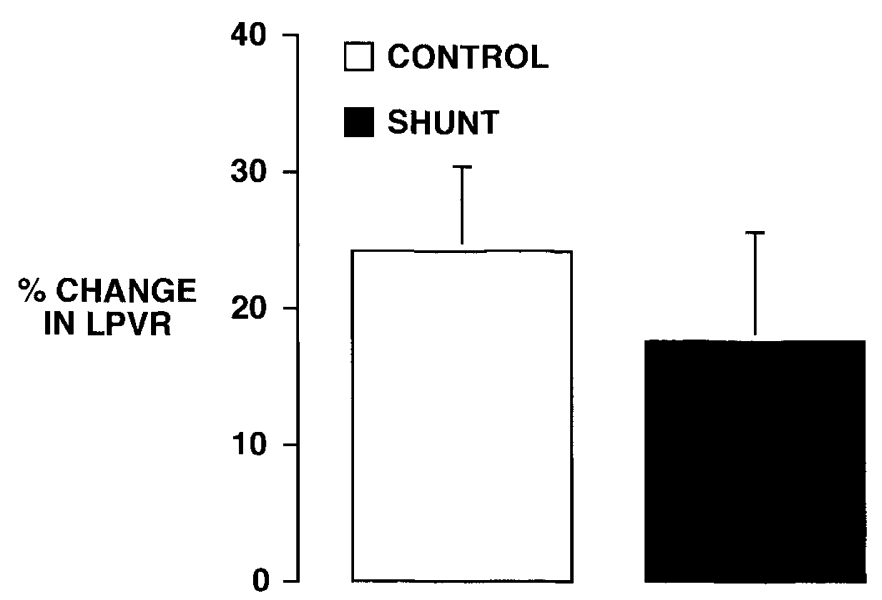

Figure 3. In shunted lambs, the increase in left pulmonary vascular resistance $(P V R)$ in response to LNA (an inhibitor of NO synthase) is unchanged from control lambs. Values are mean $\pm \mathrm{SE}$ of seven control and nine shunted lambs.

within the first years of life, before the development of significant vascular remodeling $(16,25)$. However, subsets of children with congenital heart disease may suffer significant perioperative morbidity and mortality from enhanced pulmonary vascular reactivity even within the first few months of life. For example, neonates with truncus arteriosus have a significantly higher mortality and morbidity secondary to pulmonary hyper-
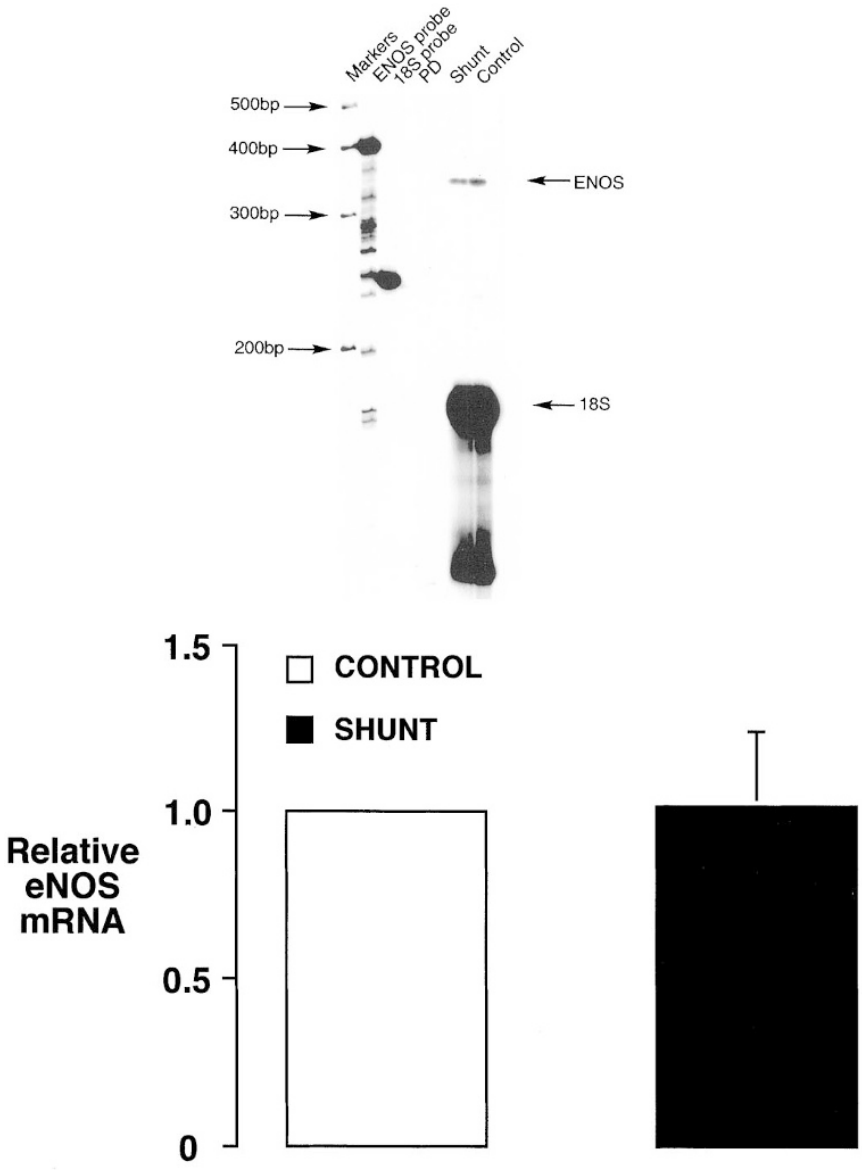

Figure 4. RNase protection assay for eNOS in peripheral lung tissue from 8-wk-old lambs. Top: A cRNA probe for ovine eNOS was hybridized overnight to $50 \mu \mathrm{g}$ of total lung RNA prepared from two 8-wk-old lambs (one control and one shunt). There were no protected fragments detected in the lane where the probe was hybridized without RNA $(P D)$. eNOS probe and $18 \mathrm{~S}$ probe are the undigested probes. A cRNA for ovine $18 \mathrm{~S}$ was also hybridized to serve as a control for RNA loading. Bottom: The densitometric values for relative eNOS mRNA (normalized to $18 \mathrm{~S}$ mRNA and to control values) from five control and five shunted lambs. In shunted lambs, relative eNOS mRNA is unchanged from control lambs. Values are mean \pm SE.

tension if they are operated after $30 \mathrm{~d}$ of life, and mortality increases even further after $100 \mathrm{~d}$ of life (26). To study potential early alterations in endothelial function secondary to increased pulmonary blood flow, we developed a novel model of pulmonary hypertension with increased pulmonary blood flow in the lamb using in utero placement of an aorta-topulmonary vascular graft. These lambs have a pulmonary-tosystemic blood flow ratio of $\sim 2-3: 1$, a mean pulmonary arterial pressure that is $40-75 \%$ of mean systemic arterial pressure, and pulmonary vascular remodeling characteristic of children with pulmonary hypertension with increased pulmonary blood flow (19). Previously, we demonstrated that at $4 \mathrm{wk}$ of age, these lambs display a selective impairment in endotheliumdependent pulmonary vasodilation. However, in contrast to advanced pulmonary vascular disease, we found evidence of increased basal NO activity in the lungs of 4-wk-old shunted lambs, which may represent an early adaptive response of the pulmonary circulation $(20,22)$. The purpose of the present study was to further characterize potential alterations in $\mathrm{NO}$ 

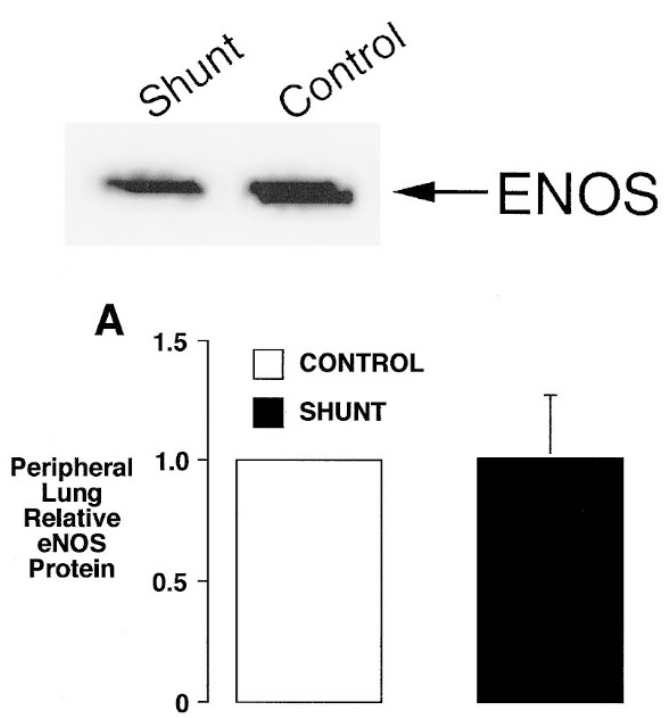

B

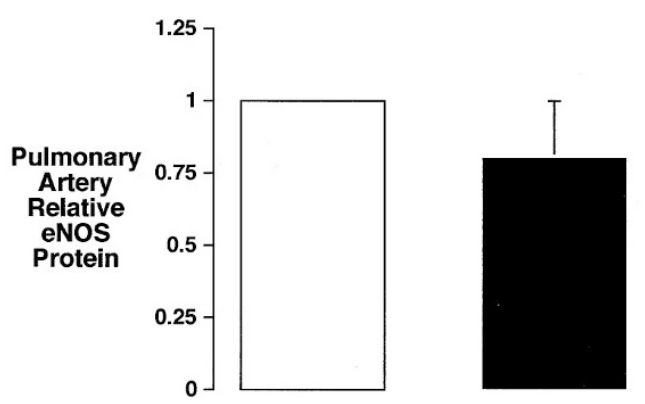

Figure 5. Western blot analysis for eNOS protein in lung tissue from 8 -wk-old lambs. Top: Representative Western blot from protein extracts (100 $\mu \mathrm{g}$ ), prepared from peripheral lung tissue from two 8-wk-old lambs (one control and one shunt), were separated on a 7.5\% SDS-polyacrylamide gel, electrophoretically transferred to Hybond membranes, and analyzed using a specific antiserum raised against eNOS. Bottom: The densitometric values for relative eNOS protein (normalized to control values) obtained from peripheral lung $(A)$ and isolated pulmonary arteries $(B)$ in five control and five shunted lambs. In shunted lambs, eNOS protein is unchanged from control lambs. Values are mean $\pm \mathrm{SE}$.

following $8 \mathrm{wk}$ of increased pulmonary blood flow and pressure. Using our lamb model, we found a persistent, selective impairment in endothelium-dependent pulmonary vasodilation. However, in contrast to the 4-wk-old lambs, we found that the pulmonary vasoconstricting response to LNA, eNOS mRNA levels, eNOS protein, NOS activity, and tissue $\mathrm{NO}_{\mathrm{X}}$ concentrations were all similar to controls, suggesting that basal NO activity was no longer up-regulated.

To investigate potential differences in agonist-induced NO responses in vivo, we studied the vasoactive effects of $\mathrm{ACH}$ and inhaled NO. ACH is a receptor-dependent, endotheliumdependent pulmonary vasodilator; it requires, at least in part, the vascular endothelium to generate NO from L-arginine (27). NO then diffuses to the vascular smooth muscle and activates sGC, resulting in increased cGMP concentrations and smooth muscle relaxation. Inhaled NO is an endothelium-independent vasodilator; it increases cGMP concentrations by the direct activation of sGC, independent of endothelial production of
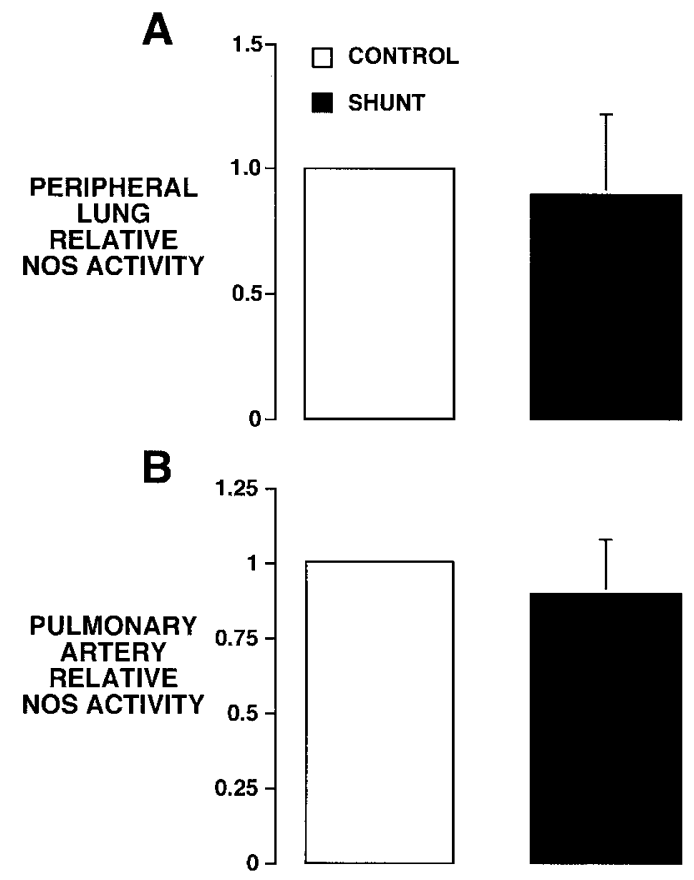

Figure 6. Using the conversion of ${ }^{3} \mathrm{H}$-arginine to ${ }^{3} \mathrm{H}$-citrulline, NOS activity ( $\mathrm{pmol} / \mathrm{min} / \mathrm{mg}$ protein) was measured in peripheral lung tissue $(A)$ and isolated pulmonary arteries $(B)$ from control and shunted lambs. In shunted lambs, NOS activity was unchanged from control lambs. Values are mean \pm SE of five control and five shunted lambs.

NO (28). In intact control lambs, both ACH and inhaled NO produced significant pulmonary vasodilation. However, in intact shunted lambs, ACH did not change pulmonary arterial pressure, and actually increased left pulmonary vascular resistance, whereas inhaled NO dilated to a similar extent as controls. Because the pulmonary vasodilating response to many vasoactive agents is dependent of the baseline tone, and minimal at rest, we studied the vasoactive responses in control lambs during pulmonary hypertension induced by the infusion of U46619, a thomboxane $\mathrm{A}_{2}$ mimic (23). In addition, we also studied the responses in control lambs at rest, and in shunted lambs with the vascular graft closed. During these two extra conditions, the altered response to ACH persisted. We found that $\mathrm{ACH}$ decreased pulmonary vascular resistance by $13.7 \%$ $(n=4, p<0.05)$ in resting control lambs, but did not significantly change pulmonary vascular resistance in shunted lambs with the vascular graft closed $(n=8)$. To further ensure that the altered $\mathrm{ACH}$ response was not related to differences in resting tone, we studied the vasoactive responses in isolated pulmonary arteries. Similar to the in vivo studies, pulmonary arteries isolated from shunted lambs demonstrated a blunted relaxation response to the endothelium-dependent vasodilator A-23187. We chose A-23187 instead of ACH for the isolated vessel protocol because its action is independent of receptor function. Relaxations to exogenous NO in the form of SNAP were not different.

The mechanisms for impaired endothelium-dependent vasodilation may be multifactorial. Previously, in 4-wk-old lambs, isolated vessel studies demonstrated that superoxide production may have a role, and that L-arginine availability and receptor alterations did not (21). The etiology in 8-wk-old 
A

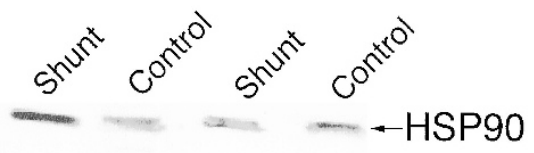

B

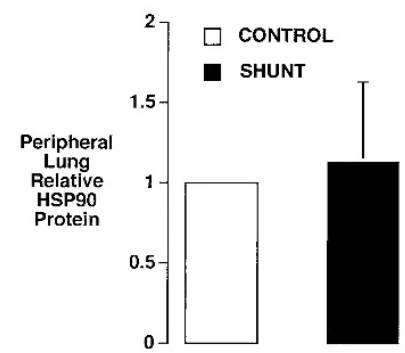

C

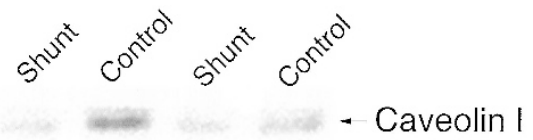

D

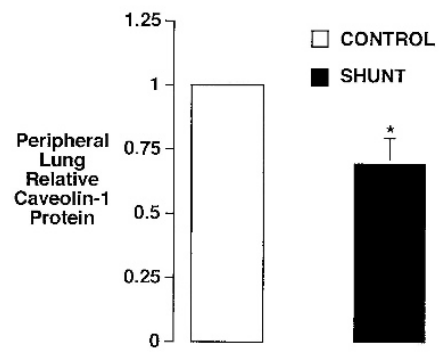

Figure 7. Western blot analysis for HSP 90 and caveolin 1 proteins in peripheral lung tissue from 8-wk-old lambs. $(A)$ Representative Western blot from protein extracts $(100 \mu \mathrm{g})$, prepared from peripheral lung tissue from two 8-wk-old lambs (one control and one shunt), were separated on a 7.5\% SDS-polyacrylamide gel, electrophoretically transferred to Hybond membranes, and analyzed using a specific antiserum raised against HSP 90. $(B)$ The densitometric values for relative HSP90 protein (normalized to control values) obtained from peripheral lung tissue in five control and five shunted lambs. In shunted lambs, HSP 90 protein is unchanged from control lambs. Values are mean \pm SE. (C) Representative Western blot from protein extracts (100 $\mu \mathrm{g})$, prepared from peripheral lung tissue from two 8-wk-old lambs (one control and one shunt), were separated on a 4-20\% SDS-polyacrylamide gradient gel, electrophoretically transferred to Hybond membranes, and analyzed using a specific antiserum raised against caveolin I. $(D)$ The densitometric values for relative caveolin 1 protein (normalized to control values) obtained from peripheral lung tissue in five control and five shunted lambs. In shunted lambs, caveolin 1 protein is reduced compared with control lambs. $p<0.05$. Values are mean $\pm \mathrm{SE}$.

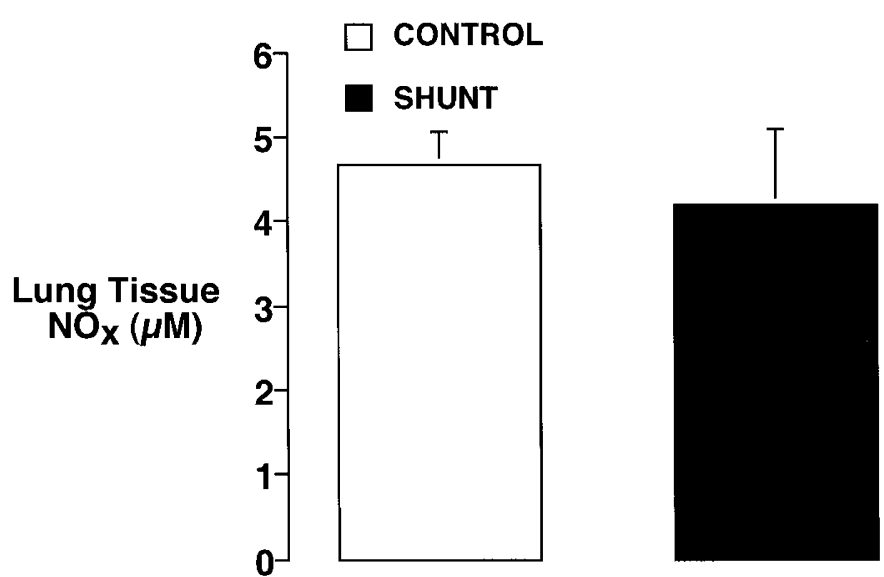

Figure 8. In shunted lambs, peripheral lung tissue concentrations of $\mathrm{NO}_{\mathrm{X}}$ are unchanged from control lambs. Values are mean $\pm \mathrm{SD}$ of five control and five shunted lambs.

lambs is unclear and requires further studies. Recent studies demonstrate that the post-translational regulation of eNOS is complex, and that both basal and agonist-induced NO production is regulated by the interaction of eNOS with other cellular proteins (24). Two important regulators are HSP 90, a positive regulator, and caveolin-1, a negative regulator. Therefore, we determined the expression of these proteins in peripheral lungs of shunt and control lambs. We found that HSP 90 levels were not altered in shunted lambs, but caveolin-1 levels were decreased in shunted lambs. Because this alteration could lead to an increase in eNOS activation, these data suggest that there are other mechanisms involved in the impaired agonist-induced NO release displayed in shunted lambs. However, the current data do suggest that the impairment in endothelium-dependent relaxation in shunted lambs is independent of differences in

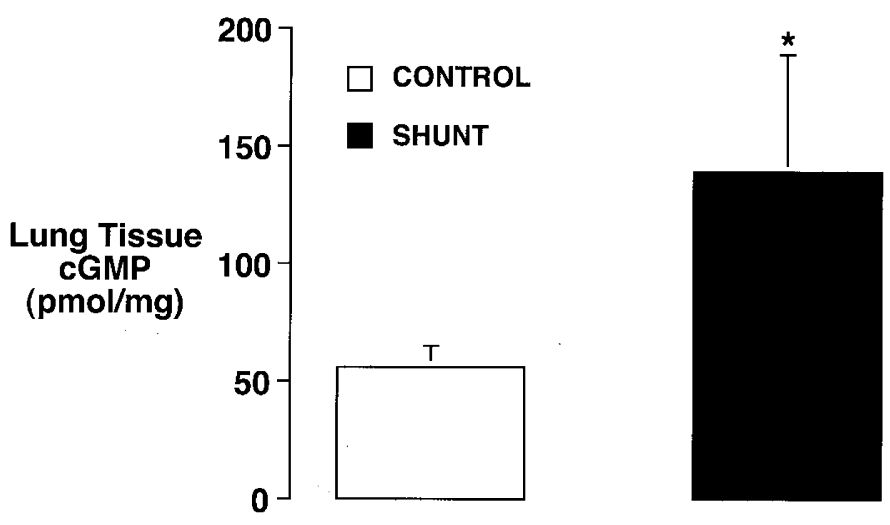

Figure 9. Using ${ }^{125}$ I RIA, peripheral lung cGMP content was measured in peripheral lung tissue of control and shunted lambs. Tissue cGMP concentrations were increased by $187 \%$ in shunted lambs. Values are mean \pm SD of five control and five shunted lambs. ${ }^{*} p<0.05 v s$ control lambs.

resting tone and receptor function. Although impaired sGC activity and/or significant smooth muscle remodeling could result in attenuated endothelium-dependent vasodilation, these explanations are unlikely in the present study, because the response to inhaled NO and SNAP remained intact.

Because the assessment of basal NO activity in vivo is indirect, we used several different determinations. First, we studied the response of the NOS inhibitor LNA. In vitro and in vivo studies indicate that the vasoconstricting response to NOS inhibition is a reflection of basal NO release $(29,30)$. Previously, we demonstrated that the pulmonary vasoconstricting response LNA was augmented in 4-wk-old shunted lambs, suggestive of increased basal NO production (20). However, in the present study, the response in 8-wk-old lambs was similar between shunted lambs and controls, suggesting that basal NO 
production is no longer increased after 8 wk of increased pulmonary blood flow and/or pressure.

To better define basal NO activity, we also determined and compared lung tissue $\mathrm{NO}_{\mathrm{X}}$ concentrations and total NOS activity. $\mathrm{NO}_{\mathrm{X}}$ is an indirect determination of total body $\mathrm{NO}$ production (31). Endogenous NO may be found as dissolved NO gas, nitrite anions, and the majority as nitrate anions. Using vanadium and $\mathrm{HCl}$ reduction, both nitrite and nitrate are reduced to NO, which is then determined by chemiluminescence. Therefore, we determined all potential sources of endogenous NO production. In addition to endogenous NO production, plasma $\mathrm{NO}_{\mathrm{X}}$ concentrations are effected by diet, changes in renal function, and changes in extracellular volume (31). Therefore, in the present study, we determined $\mathrm{NO}_{\mathrm{X}}$ concentrations in peripheral lung tissue. As noted in Figure 7, no differences in lung tissue $\mathrm{NO}_{\mathrm{X}}$ concentrations were noted between shunted and twin control lambs. In addition, we determined total NOS activity in both peripheral lung and isolated pulmonary arteries by the conversion of ${ }^{3} \mathrm{H}$-arginine to ${ }^{3} \mathrm{H}$-citrulline, and found no differences between shunted and control lambs. However, it should be noted that this assay determines all NOS isoforms, and potential differences in the endothelial isoform may be difficult to detect. Therefore, to better define potential changes in eNOS induced by $8 \mathrm{wk}$ of increased pulmonary blood flow and/or pressure, we also determined peripheral lung and isolated pulmonary artery eNOS protein levels by Western blot analysis and peripheral lung eNOS mRNA levels by RNase protection assays. As noted in Figures 4 and 5, we detected no differences in eNOS mRNA or protein between shunted and control lambs. Lastly, to ensure that potential changes in endothelial cell number did not alter our results, we normalized the eNOS protein data to Flk-1 protein. Flk-1 is a receptor tyrosine kinase specific for vascular endothelium growth factor, and whose gene expression does not appear to be altered by shear stress (32). After normalization, eNOS protein remained unchanged.

Lastly, lung tissue concentrations of cGMP, the second messenger for NO-mediated vasodilation, were determined. In contrast to our other data that suggest similar basal NO activity between 8-wk-old shunted and control lambs, but similar to our findings in 4-wk-old lambs, we found that tissue cGMP concentrations were increased in shunted lambs (22). However, the two major sources of cGMP generation are NO via sGC activation, and the natriuretic peptides, via particulate guanylate cyclase activation (33). Increases in natriuretic concentrations have been well described in humans and animals with pulmonary hypertension (34). Therefore, the persistent increase in cGMP concentrations is most likely consistent with an increase in natriuretic peptide generation, and not an increase in basal NO production. However, potential changes in sGC and/or phosphodiesterase activity may participate, and warrant further studies.

In summary, we have previously demonstrated that 4-wk-old lambs with increased pulmonary blood flow and pressure from birth have a selective impairment of endothelium-dependent pulmonary vasodilation, but evidence of increased basal NO activity (20-22). In the present follow-up study, we demonstrate that 8 -wk-old lambs with increased pulmonary blood flow and pressure maintain the selective impairment in endothelium-dependent vasodilation, but basal NO activity is no longer increased. This loss of basal NO up-regulation over the second month of life correlates with the increase in perioperative pulmonary hypertension morbidity noted in children with truncus arteriosus over $30 \mathrm{~d}$ of life (26). Therefore, we speculate that the early up-regulation of the NO-cGMP cascade is an adaptive response of the pulmonary circulation that may be responsible, in part, for the decreased perioperative morbidity from pulmonary hypertension that has been noted in neonates with high-risk congenital heart defects. However, the subsequent decrease in basal NO activity over the following months may play a role in the increasing perioperative morbidity that is noted in older infants. In addition, because decreased basal NO production has been demonstrated in humans with advanced pulmonary vascular disease, we speculate that basal NO activity will continue to decrease in shunted lambs to values that are less than control lambs. Further investigation of these changes, and their mechanisms may lead to important prevention and treatment strategies for pulmonary hypertension secondary to increased pulmonary blood flow.

Acknowledgments. The authors thank Michael J. Johengen, Sylvia F. Gugino, and Daniel Swartz for their expert technical assistance.

\section{REFERENCES}

1. Burrows FA, Klinck JR, Rabinovitch M, Bohn DJ 1986 Pulmonary hypertension in children: perioperative management. Can Anaesth Soc J 33:606-628

2. Hoffman JIE, Rudolph AM, Heymann MA 1981 Pulmonary vascular disease with congenital heart lesions: pathologic features and causes. Circulation 64:873-877

3. Wheller J, George BL, Mulder DG, Jarmakani JM 1979 Diagnosis and management of postoperative pulmonary hypertensive crisis. Circulation 60:1640-1644

4. Brashers VL, Peach MJ, Rose Jr CE 1988 Augmentation of hypoxic pulmonary vasoconstriction in the perfused rat lung by in vitro antagonists of endotheliumdependent relaxation. J Clin Invest 82:1495-1502

5. Fineman JR, Soifer SJ, Heymann MA 1995 Regulation of pulmonary vascular tone in the perinatal period. Annu Rev Physiol 57:115-134

6. Ignarro LJ 1989 Biological actions and properties of endothelium-derived nitric oxide formed and released from artery and vein. Circ Res 65:1-21

7. Yanagisawa M, Kurihara H, Kimura S, Tomobe Y, Kobayashi M, Mitsui Y, Yazaki Y, Goto K, Masaki T 1988 A novel potent vasoconstrictor peptide produced by vascular endothelial cells. Nature 332:411-415

8. Bush PA, Gonzalez NE, Ignarro LJ 1992 Biosynthesis of nitric oxide and citrulline from L-arginine by constitutive nitric oxide synthase present in rabbit corpus cavernosum. Biochem Biophys Res Commun 186:308-314

9. Palmer RMJ, Ashton DS, Moncada S 1988 Vascular endothelial cells synthesize nitric oxide from L-arginine. Nature 333:664-666

10. Mülsch A, Bassenge E, Busse R 1989 Nitric oxide synthesis in endothelial cytosol: evidence for a calcium-dependent and a calcium-independent mechanism. Naunyn Schmiedebergs Arch Pharmacol 340:767-770

11. Rubanyi GM, Romero JC, Vanhoutte PM 1986 Flow-induced release of endotheliumderived relaxing factor. Am J Physiol 250:H1145-H1149

12. Ignarro LJ, Harbison RG, Wood KS, Kadowitz PJ 1986 Activation of purified soluble guanylate cyclase by endothelium-derived relaxing factor from intrapulmonary artery and vein: stimulation by acetylcholine, bradykinin, and arachidonic acid. J Pharmacol Exp Ther 237:893-900

13. Kamisaki Y, Saheki S, Nakane M, Palmieri J, Kuno T, Chang B, Waldman SA, Murad F 1986 Soluble guanylate cyclase from rat lung exists as a heterodimer. J Biol Chem 261:7236-7241

14. Murad F 1986 Cyclic guanosine monophosphate as a mediator of vasodilation. J Clin Invest 78:1-5

15. Garg UC, Hassid A 1989 Nitric-oxide-generating vasodilators and 8-bromo-cGMP inhibit mitogenesis and proliferation of cultured rat smooth muscle cells. J Clin Invest $83: 1774-1777$

16. Celermajer DS, Cullen S, Deanfield JE 1993 Impairment of endothelium-dependent pulmonary artery relaxation in children with congenital heart disease and abnormal pulmonary hemodynamics. Circulation 87:440-446

17. Dinh-Xuan AT, Higenbottam TW, Clelland C, Pepke-Zaba J, Cremona G, Wallwork J 1990 Impairment of pulmonary endothelium-dependent relaxation in patient's with Eisenmenger's syndrome. Br J Pharmacol 99:9-10 
18. Giaid A, Saleh D 1995 Reduced expression of endothelial nitric oxide synthase in the lungs of patients with pulmonary hypertension. N Engl J Med 333:214-221

19. Reddy VM, Meyrick B, Wong J, Khoor A, Liddicoat JR, Hanley FL, Fineman JR 1995 In utero placement of aortopulmonary shunts: a model of postnatal pulmonary hypertension with increased pulmonary blood flow in lambs. Circulation 92:606-613

20. Reddy VM, Wong J, Liddicoat JR, Johengen M, Chang R, Fineman JR 1996 Altered endothelium-dependent vasoactive responses in lambs with pulmonary hypertension and increased pulmonary bloodflow. Am J Physiol 271:H562-H570

21. Steinhorn RH, Russell JA, Lakshminrusimha S, Gugino SF, Black SM, Fineman JR 2001 Altered endothelium-dependent relaxations in lambs with high pulmonary blood flow and pulmonary hypertension. Am J Physiol 280:311-317

22. Black SM, Fineman JR, Steinhorn RH, Bristow J, Soifer SJ 1998 Increased endothelial nitric oxide synthase in lambs with increased pulmonary blood flow and pulmonary hypertension. Am J Physiol 275:H1643-H1651

23. Rudolph AM, Kurland MD, Auld PAM, Paul MH 1959 Effects of vasodilator drugs on normal and serotonin-constricted pulmonary vessels of the dog. Am J Physiol 197:617-623

24. Fulton D, Gratton J-P, Sessa WC 2001 Post-translational control of endothelial nitric oxide synthase: why isn't calcium/calmodulin enough? J Pharmacol Exp Ther 299:818-824

25. Rabinovitch M, Bothwell T, Hayakawa BN, Williams WG, Trusler GA, Rowe RD, Olley PM, Cutz E 1986 Pulmonary artery endothelial abnormalities in patients with congenital heart defects and pulmonary hypertension. Lab Invest 6:632-653

26. Hanley FL, Heinermen MK, Jonas RA, Mayer JE, Cook NR, Wessel DL, Castaneda AR 1993 Repair of truncus arteriosus in the neonate. J Thorac Cardiovasc Surg 105:1047-1056
27. Fiscus RR 1988 Molecular mechanisms of endothelium-mediated vasodilation. Semin Thromb Hemost 14:12-22

28. Roberts Jr JD, Chen TY, Kawai N, Wain J, Dupuy P, Shimouchi A, Bloch K, Polaner D, Zapol WM 1993 Inhaled nitric oxide reverses pulmonary vasoconstriction in the hypoxic and acidotic newborn lamb. Circulation 72:246254

29. Conger J, Robinette J, Villar A, Raij L, Shultz P 1995 Increased nitric oxide synthase activity despite lack of response to endothelium-dependent vasodilators in postischemic acute renal failure. J Clin Invest 96:631-638

30. Fineman JR, Heymann MA, Soifer SJ 1991 N $\omega$-nitro-L-arginine attenuates endothelium-dependent pulmonary vasodilation in lambs. Am J Physiol 260:H1299H1306

31. Zeballos GA, Bernstein RD, Thompson CI, Forfia PR, Seyedi N, Shen W, Kaminiski PM, Wolin MS, Hintze TH 1995 Pharmacodynamics of plasma nitrate/nitrite as an indication of nitric oxide formations in conscious dogs. Circulation 91:2982-2988

32. Chen K, Li Y, Kim M, Li S, Yuan S, Chien S, Shyy J 1999 Mechanotransduction in response to shear stress. J Biol Chem 274:18393-18400

33. Garbers DL 1992 Guanylate cyclase receptor and their endocrine, paracrine, and autocrine ligands. Cell 71:1-4

34. Nagaya N, Nishikimi T, Okano Y, Uematsu M, Satoh T, Kyotani S, Kuribayashi S, Hamada S, Kakishita M, Nakanishi N, Takamiya M, Kunieda T, Matsuo H, Kangawa K 1998 Plasma brain natriuretic peptide levels increase in proportion to the extent of right ventricular dysfunction in pulmonary hypertension. J Am Coll Cardiol 31:202208 